\title{
LANDASAN PENDIDIKAN AKHLAK MENURUT HAMKA
}

\author{
SYIFA TSAMROTUL FUADI \\ HASAN BISRI \\ SUMADI
}

\begin{abstract}
Moral education is education which is about the basics of morals (morals) and the virtue of character, the traits a child must have from childhood until he becomes a convert. Morals are closely related to human thought patterns, attitudes and behavior. Good morals or noble morals are attitudes and behaviors that must be possessed by every Muslim, either directly related to Allah Almighty, or to His creatures. Regarding the moral education, the researcher studied the thoughts of Haji Abdul Malik Karim Amrullah (HAMKA), a prominent scholar from Minangkabau. This study is to determine the moral education according to HAMKA, both for students and for the community. Moreover, some of HAMKA's thoughts on Islamic Education, many say that the form of all his thoughts on the issue of Education is to emphasize more on mental education or morals. The objectives of this research are: 1) To know the basis of moral thought according to HAMKA, 2) To know the purpose of moral education according to HAMKA, and 3) To find out the moral education according to HAMKA and its relevance to Islamic religious education. This study uses library research (library research) with descriptive analysis method, namely by collecting data, compiling and classifying, compiling and interpreting it. This descriptive study was carried out by collecting data, classifying the data, then formulating the rules for compliance contained in the data. The results of the research conducted by the intruder is that according to HAMKA, the moral basis is an inner temper that can change so that if it arises based on reason and religion, a good character will emerge and vice versa if it arises not based on reason and religion, a bad character will appear or is often called with a despicable character. The sources of moral education according to HAMKA are the Koran, Assunah, tawhid, and reason.
\end{abstract}

Keywords: Moral education, HAMKA, Islamic education.

\section{Pendahuluan}

Pendidikan akhlak dalam agama Islam ialah pendidikan yang mengakui dalam kehidupan di dunia ini manusia menghadapi hal yang baik dan hal yang 
buruk, keadilan dan kezaliman, kebenaran dan kebathilan, serta perdamaian dan peperangan. Untuk bisa mengatasi hal-hal yang serba kontra tersebut, Islam telah menetapkan prinsip-prinsip untuk umatnya supaya bisa hidup di dunia ini. Dengan demikian, manusia mampu mewujudkan kebaikan di dunia dan akhirat, serta mampu berinteraksi dengan orang-orang yang baik atau jahat yang ada disekitarnya.

Pendidikan akhlak yaitu pendidikan yang mengenai dasar-dasar moral (akhlak) dan keutamaan tabiat, perangai, yang harus dimiliki oleh seorang anak dari masa kanak-kanak hingga ia menjadi mukallaf. Tak dapat diragukan lagi, bahwa keutamaan moral, tabiat, perangai yaitu salah satu buah iman yang sangat mendalam. Akhlak sangat erat kaitannya dengan pola pikir, sikap hidup dan perilaku manusia. Keburukan akhlak sangat berakibat memicunya timbul perilaku-perilaku negatif. Misalnya, seseorang yang mempunyai perilaku buruk maka besar kemungkinan ia akan melahirkan berbagai perilaku buruk yang dapat merugikan dirinya bahkan orang yang ada disekitarnya. Akhlak yang baik dapat membentuk pribadi seorang muslim yang dapat membawa nilai-nilai positif sehingga dapat membentuk dirinya sebagai seorang muslim yang taat kepada Allah swt (Muflihaini, 2017: 24).

Kemerosotan moral yang melanda bangsa Indonesia saat ini, terutama dikalangan remaja yang akan menjadi generasi penerus bangsa sangat memprihatinkan. Kejadian ini dampak dari perkembangan yang tidak diimbangi dengan kesiapan mental dalam mengonsumsi dan menerima teknologi yang semakin berkembang saat ini. Secara garis besar, penyebab utama masalahnya adalah berkembangnya teknologi modern dikalangan remaja dan masyarakat yang semakin sulit untuk dikontrol penggunaannya. Seharusnya, penggunaan teknologi yang semakin modern ini diimbangi dengan pembinaan iman dan takwa yang semakin kuat. Terutama kepada para remaja sebagai generasi penerus bangsa (Darojah, 2016: 02).

Pendidikan zaman sekarang banyak sekali mengalami perubahan moral dan hilangnya nilai-nilai sosial yang ditandai dengan pergaulan bebas, tawuran antar anak sekolah, narkoba, dan masih banyak yang lainnya. Hal ini merupakan sebagian dari perilaku menyimpang remaja bahkan orang dewasa sekalipun. Maka tidak mengherankan jika generasi muda yang kehilangan arah di dalam lingkungan primernya, yaitu keluarga dalam menghadapi keadaan yang jauh lebih parah di dalam masyarakat sekitarnya.

Semakin terlihat jelas meningkatnya fenomena tingkah laku kekerasan di kalangan remaja dan pemuda, perjudian, perkelahian, ketidakjujuran, krisis kewibawaan, penyelewengan seksual, meningkatnya egoisme serta menurunnya tanggung jawab sebagai warga negara. Singkatnya para remaja cenderung suka berperilaku merusak dirinya dan kebutaan etika. Pada intinya para remaja sangat mengkhawatirkan dan diambang kritis yang sangat mengkhawatirkan baik orang tua maupun pendidik (Zuriah, 2011: 11). 
Bagi peserta didik zaman milenial, dengan adanya rasa hormat, kasih sayang, segan atau yang kita kenal dengan istilah ( $t a^{\prime}$ dhim) terhadap guru ataupun orang tua semakin hilang, hal ini karena peserta didik kurang dalam menghayati dan melaksanakan atau mempraktikan apa yang telah dipelajari di sekolah seperti dalam mata pelajaran akidah akhlak atau dalam ilmu budi pekerti yang dikenal dengan istilah sopan santun (Nurhidayat, 2017: 18).

Realita lain yang terjadi di dunia pendidikan pada saat ini ialah titik berat pendidikan lebih banyak pada masalah kognitifnya saja. Kelulusan pun masih ditentukan dengan nilai akademik dan kurang melihat akhlak dan budi pekerti peserta didik. Dunia pendidikan sangat meremehkan mata pelajaran yang berkaitan dengan pembentukan karakter. Di sisi lain, tidak dipungkiri dengan mengajarkan pelajaran-pelajaran yang mengembangkan karakter bangsa seperti pendidikan pancasila, pendidikan kewarganegaraan, pendidikan agama Islam, ilmu pengetahuan sosial, dalam pelaksanaan pembelajarannya lebih menekankan pada aspek kognitif daripada aspek afektif dan psikomotorik. Di samping itu, penilaian dalam mata pelajaran yang berkaitan dengan pendidikan belum secara total untuk mengukur sosok pribadi siswa (Nata, 2014: 323).

Dari uraian di atas, peneliti mencoba mempelajari pemikiran Haji Abdul Malik Karim Amrullah (HAMKA) yaitu salah satu tokoh ulama yang berasal dari Minangkabau. Kajian ini tujuannnya untuk mengetahui pendidikan akhlak menurut HAMKA baik untuk peserta didik, maupun untuk di lingkungan masyarakat. Terlebih beberapa pemikiran HAMKA mengenai pendidikan Islam, banyak mengatakan bahwa segala segala bentuk pemikirannya tentang masalah pendidikan ialah lebih menekankan kepada pendidikan jiwa atau akhlakul karimah, jadi dalam hal ini penulis ingin mengetahui lebih jauh tentang pendidikan akhlak yang dikemukakan oleh HAMKA.

Alasan yang menjadi tolak ukur penulis meneliti pemikiran HAMKA yaitu beliau bukan sekedar ilmuan ataupun sastrawan, melainkan seorang ulama era modern yang banyak memberikan kontribusi dan mengembangkan peradaban dinamika intelektual masyarakat Islam. HAMKA sosok ulama yang gigih dan mengubah pola hidup tradisonal kepada pola hidup dinamis dan rasional, HAMKA juga merupakan sosok ulama pendidik dan ulama yang memiliki lautan ilmu. selain itu juga karya-karyanya merupakan perkembangan pola pendidikan yang dilaksanakan di masyarakat Islam pada waktu itu.

Salah satu karya HAMKA yang paling fenomenal yaitu Tafsir Al-Azhar, HAMKA tujukkan untuk masyarakat umum. HAMKA memberikan perumpamaan-perumpamaan dari kehidupan sehari-hari dan budaya-budaya dimana ia bertempat tinggal, sehingga para pembaca mudah untuk memahami dan mengaplikasikan ajaran-ajaran Al-Qur'an. Selanjutnya Tafsir Al-Azhar ini memberikan kesan bahwa Al-Qur'an mampu didekati oleh masyarakat awam, 
bukan hanya kaum elit, cendikiawan, dan tokoh agama. Sehingga Al-Qur'an menjadi petunjuk masyarakat dalam menjalani hidup. Sedangkan Tafsir AlMisbah salah satu karya ulama Indonesia juga yaitu Muhammad Quraish Shihab, lebih mengedepankan kepada bidang-bidang akademis seperti sistematika penyusunan ayat-ayat dan surat-surat yang sangat unik dan mengandung unsur pendidikan yang sangat menyentuh dan keinginan untuk memperjelas makna-makna yang dikandung oleh suatu ayat.

\section{Kajian Teoretik}

\section{Konsep Pendidikan Akhlak}

Pendidikan adalah suatu upaya untuk meningkatkan martabat manusia yang terlahir dalam keadaan ketidaktahuan, supaya memiliki pengetahuan sehingga bisa menjadikan seluruh kehidupannya menuju kearah yang memuaskan, dapat meramalkan berbagai jenis keterampilan dan kemahiran di masa yang akan datang, dan memiliki bekal kemampuan belajar, supaya dapat terus menerus belajar di sepanjang hidupnya (Al-Hamdani, 2018: 01).

Ahmad Tafsir menjelaskan bahwa pendidikan ialah berbagai usaha yang dilakukan oleh seorang pendidik terhadap peserta didik agar mencapai perkembangan maksimal yang positif. Usaha itu banyak macamnya. Salah satunya ialah dengan cara mengajarnya, yakni mengembangkan pengetahuan dan keterampilannya. Selain itu, juga ditempuh usaha yang lain, yaitu memberikan contoh agar bisa ditiru, membiasakan, memberikan suatu pujian dan hadiah, dan sebagainya yang tidak terbatas (Tafsir, 2016: 37).

\section{Konsep Pendidikan Agama Islam}

Pendidikan agama Islam adalah pendidikan yang berdasarkan Islam. Islam adalah nama agama yang dibawa oleh Nabi Muhammad saw. Islam berisi tentang seperangkat ajaran tentang kehidupan manusia, ajaran itu dirumuskan berdasarkan dan bersumber pada Al-Qur'an dan Hadits serta akal. Jika demikian, pendidikan agama Islam adalah ilmu pendidikan yang berdasarkan Al-Qur'an, Hadits, dan akal. Penggunaan dasar itu haruslah berurutan: Al-Qur'an terlebih dahulu, bila tidak ada atau tidak jelas bisa dilihat di dalam Hadits, bila tidak ada barulah digunakan akal (pemikiran), tetapi temuan akal itu tidak boleh bertentangan dengan jiwa A-Qur'an dan Hadits (Tafsir, 2016: 18).

Sedangkan menurut (Darajat, 2011: 86) pendidikan agama Islam yaitu pendidikan yang melalui ajaran-ajaran agama Islam, yakni dengan membimbing dan mengasuh anak didik supaya nanti setelah selesai dari pendidikan ia bisa memahami, menghayati, sekaligus mengamalkan ajaranajaran agama Islam yang telah diyakini secara menyeluruh, serta meyakini ajaran agama Islam secara menyeluruh dan menjadikan ajaran agama Islam itu sebagai suatu pandangan hidupnya demi keselamatan di dunia dan di akhirat. 


\section{Konsep Akhlak}

Secara etimologi (bahasa) kata akhlak berasal dari bahasa Arab yang berarti akhlaq, yang merupakan bentuk jama' dari kata khuluq. Kata khuluq yang berarti budi pekerti, tabiat, perangai atau tingkah laku. Begitu pun dalam bahasa Yunani, pengertian khuluq sama artinya dengan kata ethicos, yang merupakan perasaan batin, adab kebiasaan, serta kecenderungan hati untuk melakukan suatu perbuatan. Kata ethicos kemudian diubah menjadi etika. Kata khuluq juga disebutkan dalam kitab suci Alquran surat Al-Qalam: 04 yang artinya: "Dan sesungguhnya kamu benar-benar berbudi pekerti yang agung." Firman Allah swt tersebut menunjukkan bahwa khuluq merupakan tingkah laku Rasulullah saw, yang telah menjadi kebiasaan (Mustopa, 2014: 265-266).

Akhlak seringkali diartikan dengan etika dan moral. Etika dan moral berasal dari bahasa Yunani yang berartikan sama yaitu kebiasaan. Sedangkan kata budi pekerti berasal dari bahasa Indonesia yang merupakan kata majemuk dari kata budi dan pekerti. Budi berasal dari bahasa sansekerta yang artinya sadar, sedangkan pekerti berasal dari bahasa Indonesia sendiri yang mempunyai arti kelakuan. Sedangkan moral berasal dari bahasa latin mores yang berarti jamak dari kata mos yang mempunyai arti kebiasaan. Dalam kamus besar bahasa Indonesia dikatakan bahwa moral ialah penentuan baik atau buruk perbuatan dan kelakuan. Adapun kata etika berasal dari bahasa Yunani. Ethos yang berarti watak kesusilaan atau adat. Dalam kamus besar bahasa Indonesia etika diartikan sebagai asas-asas akhlak (moral) (Nata, 2010: 02).

Sedangkan menurut terminologi (istilah), akhlak ialah daya dan kekuatan yang mendorong perilaku dengan mudah dan secara spontanitas tanpa dipikirkan dan direnungkan kembali. Dengan ini, akhlak ialah suatu sikap yang melekat erat pada seseorang dan telah terwujud dalam perbuatannya. Penggunaan kata ini berlaku untuk seluruh umat manusia, tidak dikuhususkan untuk umat muslim saja. Tetapi, diakui bahwa kata akhlak selalu spontan dan diakui kepada kaum muslimin yang melakukan perbuatan baik atau buruk. Apabila perbuatan tersebut baik menurut standar Islami dan sumber ajarannya, maka tindakan tersebut dianggap perbuatan baik atau akhlak karimah (mahmudah). Sebaliknya apabila perbuatan tersebut dianggap sebagai perbuatan buruk maka perbuatan tersebut disebut dengan akhlak qabihah (mazmumah). Unutuk melihat apakah akhlak itu termasuk kedalam akhlak yang baik atau akhlak yang buruk, itu bisa didasarkan pada sumber nilai-nilai yang ada dalam Islam, yaitu Al-Qur'an dan Sunnah Rasul (Nur, 2016: 08).

\section{Metode}

Penelitian ini adalah menggunakan penelitian studi kepustakaan (library research), yaitu data dikumpulkan dan diolah dari sumber-sumber kepustakaan yang telah ditelaah secara komprehensif. Penelitian ini dtulis 
dari hasil studi bahan pustaka yang relevan, baik dari bentuk jurnal, artikel, buku yang terkait dengan masalah penelitian. Data yang dikumpulkan dalam penelitian ini adalah data kualitatif yang bersifat tekstual dalam pandangan dan pemikiran yang ada di dalam bahan pustaka tersebut.

Metode yang digunakan dalam teknik pengumpulan data adalah teknik dokumenter, yakni data dikumpulkan melalui dokumen dengan tujuan sebagai bahan pustaka. Data yang dikumpulkan dalam penelitian ini kemudian dianalisis menggunakan analisa isi. Teknik pengumpulan data dalam penelitian ini, lebih menekankan pada teknik analisa isi atau content analysis, yakni metode yang bisa digunakan untuk menganalisis semua bentuk komunikasi. Dengan menggunakan metode analisis isi akan memperoleh suatu hasil atau pemahaman terhadap isi pesan komunikasi yang disampaikan sumber informasi yang lain secara objektif, sistematis, dan relevan (Suprayogo \& Tobroni, 2001).

\section{Hasil Penelitian dan Pembahasan}

Haji Abdul Malik Karim Amrullah atau lebih dikenal dengan nama HAMKA adalah seorang ulama, sastrawan dan juga seorang politikus yang terkenal di Nusantara. HAMKA lahir di Batang Maninjau (Sumatera Barat) pada 14 Muharram 1326 H (17 Februari 1908 M) dan wafat di Jakarta pada 24 Juli 1981pada usia 73 tahun. Ayah HAMKA seorang ulama terkenal, yakni Dr. Haji Abdul Karim Amrullah atau Haji Rasul, HAMKA ialah pembawa pahampaham pembaharuan di Minangkabau. Nama HAMKA melekat pada dirinya setelah ia melaksanakan ibadah Hajin ke Makkah untuk pertama kalinya pada tahun 1927 M (Mohammad, 2006: 60). Nama HAMKA tentu saja singkatan dari Haji Abdul Malik Karim Amrullah.

Pada masa kecil, HAMKA menerima dasar-dasar agama dan belajar membaca Al-Qur'an langsung dari ayahnya. Pada usia 6 tahun, HAMKA dibawa oleh ayahnya ke Padang Panjang, kemudian pada usia 7 tahun ia dimasukkan ke sekolah desa hanya sempat dienyam selama 3 tahun dan malamnya belajar mengaji dengan ayahnya sampai khatam (Nizar,2008: 18). Selebihnya ia belajar sendiri. Karena kesukaannya mempelajari sastra HAMKA tidak ada kesulitan untuk mempelajari bahasa Arab. Dari sinilah HAMKA mengenal dunia secara luas, baik dari hasil pemikiran Arab klasik maupun Barat. Karya pemikir Barat HAMKA dapatkan dari hasil penerjemahan bahasa Arab. Melalui bahasa pula HAMKA belajar menulis apa saja, diantaranya puisi, novel, cerpen,tasawuf, dan artikel-artikel tentang dakwah (Mohammad, 2006: 60).

Besarnya prestasi dan peran HAMKA dalam melaksanakan dakwah Islamiyah di Indonesia, menarik akademisi untuk memberikan penghargaan kepada HAMKA. Pada tahun 1959 Majelis Tinggi Universitas Al-Azhar Kairo memberikan penghargaan gelar Ustadziyah Fakhriyah (Doktor Honoris Causa) kepada HAMKA, karena jasanya menyebarkan agama Islam dengan berbahasa Indonesia yang indah. Pada tahun 1974 HAMKA juga mendapatkan gelar 
Doctor Honoris Causa dalam bidang sastra dari Universitas di Malaysia (Hamim, 2009).

Konsep Pendidikan Akhlak Menurut HAMKA

Salah satu kelebihan dan perbedaan manusia dengan makhluk yang lain adalah bilamana manusia bergerak, gerak dan geriknya akan timbul dari dalam, bukan datang dari luar. Setiap langkah yang dilangkahkan, segala usaha, pekerjaan, itu semua ditimbulkan dari maksud tertentu dan datang dari suatu perasaan yang paling tinggi, yang memiliki kekuatan penuh dalam dirinya. Berbeda dengan binatang. Gerak gerik binatang mengandalkan kepada gharizah (instinch) semata-mata, tidak disertai oleh pertimbangan (HAMKA, 2018: 01).

HAMKA berpendapat bahwa akhlak adalah suatu persediaan yang sudah ada, terhujam dan raasikh di dalam batin. Dialah yang menimbulkan perangai sehingga tidak perlu untuk berfikir kembali. Apabila persediaan itu tidak dapat menimbulkan perangai yang mulia (mulia menurut syara'), perangai yang terpuji, itulah yang dinamakan dengan akhlak yang baik. Namun, apabila yang berkembang ialah akhlak tercela menurut akal dan syara' maka otomatis dinamakan akhlak yang buruk. Dikatakan bahwa akhlak adalah perangai yang terhujam dalam batin, karena ada juga bersedia orang yang menafkahkan hartanya dengan ringan saja, tetapi tidak bersumber dari akhlak yang terhujam, semata-mata ada maksud dan tujuan didalamnya (HAMKA, 2017: 05-06).

Akhlak yang baik merupakan perangai dari para Rasul, sifat orang muttaqin, orang terhormat, dan hasil perjuangan orang yang 'abid. Sedangkan akhlak yang buruk bagaikan racun berbisa, kejahatan dan kebusukan yang menjauhkan diri dari Allah swt. Akhlak yang buruk akan menyebabkan dirinya terusir dari jalan Allah swt dan tersesat kepada jalan setan. Akhlak buruk juga membukakan kita menuju pintu neraka yang bernyala dan menghanguskan hati nurani, sedangkan akhlak yang baik bagaikan pintu menuju ridho Allah swt (HAMKA, 2017: 01-02).

Setelah mengetahui pengertian akhlak dapat dipahami bahwa pendidikan akhlak menurut HAMKA yaitu suatu perangai dalam bathin yang dapat berubah sehingga apabila timbul berdasarkan akal dan agama maka akan muncul perangai yang baik dan sebaliknya apabila timbul tidak berdasarkan akal dan agama maka akan muncul perangai yang buruk atau sering disebut dengan akhlak tercela.

Sumber Akhlak Menurut HAMKA

Ajaran yang di bawa oleh para Nabi sejak awal hingga masa sebelum lahirnya agama Islam, selalu menjaga martabat kemanusiaan agar tidak mengalami penurunan yang berakibat menyamai kebinatangan. Kedudukan akhlak dalam Islam sangatlah penting, karena akhlak merupakan buah daripada tauhid yang tertanam dalam jiwa manusia. Untuk menjadi manusia 
yang baik dan berbudi luhur, HAMKA membagi sumber akhlak sebagai berikut:

1) Al-Qur'an dan Assunah

Dalam ajaran agama Islam, landasan normatif akhlak manusia adalah Al-Qur'an dan Assunah. Diantaranya adalah firman Allah swt sebagai berikut:

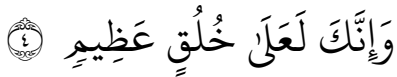

"Dan sesungguhnya kamu benar-benar berbudi pekerti yang agung." (Q.S. AlQalam: 04)

Dalam tafsirnya (HAMKA, 2015: 7567) inilah satu pujian yang paling tinggi yang diberikan oleh Allah swt kepada Rasul-Nya, yang jarang diberikan kepada Rasul yang lain selain Nabi Muhammad saw. Ayat diatas menyatakan bahwa Nabi Muhammad saw memiliki akhlak yang paling mulia. Oleh karena itu, seluruh umat manusia yang beriman kepada Nabi Muhammad saw, wajib menjadikan akhlak beliau sebagai rujukan perilaku dan suri tauladan (Saebani \& Hamid, 2017: 51)

2) Tauhid

Kata tauhid berasal dari bahasa Arab, yaitu "wahadda, yuwahiddu, tauhidan," yang artinya ialah mengesakan Allah swt. Tauhid secara bahasa adalah meyakini keesaan Allah swt atau meyakini bahwa Tuhan hanya satu yaitu Allah swt, tunggal tidak ada sekutu baginya. Menurut istilah tauhid adalah bahwa di dunia ini hanya ada satu Tuhan yang wajib untuk di sembah yaitu Allah swt yakni Tuhan sekalian alam (Dusar, 2001: 01).

Menurut HAMKA tauhid inilah yang sebenarnya sumber kekuatan dalam kehidupan seorang muslim dan sekaligus sebagai sumber akhlak. HAMKA menyatakan bahwa percaya kepada Allah swt itulah yang menghilangkan segala rasa takut, ragu, curiga, dan bimbang. Kemudian HAMKA mengatakan perasaan tauhid itulah yang menyebabkan terpandangnya, murahnya harga diri dan bersedia mati untuk memperjuangkannya, karena pada ajaran tauhid itu hakikat mati tidaklah begitu besar lagi, Yang Maha Besar adalah menuntut ridha Allah swt, itulah yang dinamai I'tikad atas kepercayaan, mabdaa atau pokok pertama dari pendirian dan itulah hakikat yang membentuk budi dalam ajaran Nabi dan junjungan kita Nabi Muhammda saw (HAMKA, 2018: viii).

3) Akal

Akal menurut HAMKA adalah anugerah Tuhan kepada makhluk yang dipilihnya, yaitu manusia (HAMKA, 2018: 185). Sebagai anugerah terhadap makhluk pilihan, akal memiliki hubungan yang menjadi dasar yang membedakan antara manusia dengan makhluk yang lain untuk berbuat sesuatu. Dengan akal itulah manusia melakukan perenungan, dan pada giliran berikutnya melakukan penelitian terhadap fenomena yang ada dalam semesta (HAMKA, 2018: 182). 
Ada yang paling penting pada diri manusia adalah akalnya, dengan akal tersebut manusia sanggup membedakan dan menyisihkan diantara yang baik dan yang buruk. Manusia melihat alam dengan panca indranya maka, menggetarlah yang kelihatan atau yang kedengaran itu ke dalam jiwa. Oleh karena itu, tergambarlah bekasnya itu didalam jiwa dan menjadi kenangan. Dengan melihat dan mendengar, tergambar dan mengenang itulah manusia membentuk persediaannya menempuh hidup. Dengan itu pulalah ia dapat mengenal mana yang baik dan mana yang buruk, mana yang jelek dan mana yang indah (HAMKA, 2018: 182).

Keutamaan Akhlak Menurut HAMKA

Keutamaan dari akhlak itu ada empat perkara, yaitu hikmah, syajaa'ah, iffah, dan adalaah (bersikap adil) (HAMKA, 2017: 06).

\section{1) Hikmah}

Hikmah artinya bijaksana. Yakni keutamaan yang diberikan oleh Allah swt kepada manusia, supaya manusia dapat mengendalikan syahwatnya dan kemarahannya, jangan sampai melantur. Ahli hikmah disebut "Hakim", sedangkan jamaknya adalah "Hukama" (HAMKA, 2018: 226).

Menurut (HAMKA, 2015: 656), hikmah itu lebih luas daripada ilmu. bahkan ujung daripada ilmu adalah awal mula daripada hikmah. Hikmah juga bisa diartikan dengan mengetahui yang tersirat dibelakang yang tersurat, mencermati yang ghaib dari melihat yang nyata, mengetahui kepastian ujung karena sudah mengetahui pangkalnya. Ahli hikmah melihat "cewangan di langit yang panas, gabak di hulu tanda hujan" perasaan ahli hikmah adalah halus. Karena mereka melihat alam maka mereka mengenal Tuhan. Oleh karena itu, dalam bahasa Indonesia, hikmah disebut bijaksana dan dalam bahasa Arab ahli hikmah disebut dengan Al-Hakim, yang berarti salah satu nama dari 99 Asmaul Husna. Oleh karena itu, kekayaan paling tinggi yang Allah swt berikan kepada hamba-Nya yaitu kekayaan hikmah.

2) Syajaah

Menurut (HAMKA, 2015: 81) syajaa'ah artinya adalah membangkitkan keberanian menempuh suatu perbuatan yang membawa kepada kemaslahatan. Syajaa'ah terbagi dalam dua kategori, yaitu keberanian semangat dan keberanian budi. Keberanian semangat ini ada pada diri serdadu menghadapi musuh di medan perang. "Walau bagaimanapun hebatnya granat, bom, meriam, bedil, peluru, gas beracun yang ada dihadapannya, dia akan terus maju dan maju terus tidak kenal mundur." Sedangkan keberanian budi ialah keberanian menyatakan suatu perkara yang diyakini sendiri kebenarannya, walaupun pada akhirnya akan dibenci oleh orang lain. Menurut HAMKA inilah yang dalam Islam dikenal dengan "Amar bil ma'ruf, nahyi anil munkar," menyuruh berbuat baik dan meninggalkan perbuatan buruk. HAMKA menegaskan "Tidaklah suatu bangsa akan berdiri tegak, dan suatu paham dapat berdiri, apabila dalam bangsa itu sendiri tidak ada yang berani menyatakan kebenaran" (HAMKA, 2015: 246). 


\section{3) Iffah}

Iffah adalah mengekang kehendak hawa nafsu dengan akal dan syara' (HAMKA, 2017: 06). Iffah yang berarti menahan diri agar terhindar dari segala perbuatan tercela yaitu keutamaan kekuatan syahwat bahimiyat, yaitu kekuatan syahwat yang sangat mudah untuk mengikuti kekuatan akal, sehingga kesedihan dan kegembiraan sesuai petujuk yang diperintahkan oleh akal (Kasron, 2017: 113).

Iffah diselubung oleh dua budi pekerti tercela, yaitu keterlaluan syahwat dan kemewahan syahwat. Keterlaluan syahwat adalah semangat yang menggebu-gebu untuk mendapatkan kemewahan, kelezatan, kesenangan, yang dianggap buruk oleh kekuatan akal, dan akal berupaya untuk mencegahnya. Sementara maksud dari kelemahan syahwat yaitu upaya untuk bangkit setelah mencapai sesuatu yang diinginkan oleh akal. Kedua sifat tersebut tergolong kepada sifat tercela. Oleh karena itu, untuk menetralisir kedua sifat tersebut diperlukan iffah untuk menyeimbangkannya sehingga menjadi sifat yang terpuji (Kasron, 2017: 113).

Manusia diwajibkan untuk mengawasi syahwat, biasanya orang cenderung akan mengikuti syahwatnya, terutama menyangkut dengan alat kelamin dan perut, kehendak untuk mendapatkan harta yang banyak, pangkat dan kedudukan yang tinggi, yang dibarengi dengan gila hormat. Keterlaluan dan kekurangan dalam sifat-sifat tersebut adalah cacat dan merupakan suatu kekurangan, sedangkan yang sempurna adalah keseimbangan menurut ukuran akal yang sehat dan agama yang benar.

\section{4) Adalaah}

Adalaah merupakan perangai mulia dari akal budi, daripada nafsu marah, dan daripada syahwat. Maksud adalaah disini yaitu kepandaian mencampurkan garam kehidupan sehingga marah ada, syahwat ada, dan akal budi pun ada. Kita menjadi seorang ahli hikmah dimana kita diperlukan, berjuang pada waktunya, menghadapi musuh pada waktunya, memandang kematian dengan ringan dan perkara kecil untuk mempertahankan kehormatan yang harus dibela. Cabangnya ialah adil dalam masyarakat, walaupun terhadap diri sendiri, adil juga di dalam melakukan siasat dan muslihat. Adil di dalam budi pekerti adalah perangai iffah. Adil menghadapi lawan ialah memakai perangai syajaa'ah. Adil di dalam pergaulan ialah menghindari kelengahan dan kelalaian. Adil di dalam melakukan siasat masyarakat ialah menenggelamkan kepentingan diri sendiri ke dalam kepentingan bersama (HAMKA, 2018: 228).

Metode Menanamkan Akhlak Kepada Manusia Menurut HAMKA

Dalam metode menanamkan akhlak HAMKA mengistilahkan dengan keutamaan dan adab kesopanan.

1) Keutamaan

Maksud dengan keutamaan dalam pembahasan akhlak atau etika adalah hal-hal yang terkait dengan kebaikan dan kemuliaan budi pekerti, 
menurut HAMKA yang lebih utama ialah orang yang berpendirian sederhana, dipikirkannya kaum keluarganya dengan kepentingan kaum dan bangsa dan masyarakat umumnya. Tumbuh rasa di dalam hatinya bahwa sebagai orang hidup dia wajib berbuat baik kepada segenap yang bernyawa, manusia atau binatang dan dirinya sekalipun (HAMKA, 2015: 79).

Kesimpulannya keutamaan itu terjadi sesudah perjuangan bathin. Di dalam kehidupan selalu terjadi perjuangan diantara hawa nafsu dengan akal yang waras, hawa nafsu mengajak mengerjakan yang memberi mudarat dan akal mengajak untuk mengerjakan hal yang bermanfaat. Tidak ada orang yang terus saja mengerjakan yang bermanfaat itu sebelum terjadi perjuangan. Bilamana akalnya menang, dipilihnya yang manfaat, jadilah dia seorang yang utama. Apabila terjadi yang sebaliknya, jadilah ia seorang yang durjana, perangai yang baik sebelum dibiasakan, tetap melalui perjuangan. Seorang yang utama senantiasa membiasakan mengerjakan apa yang disuruh akalnya. Mual-mula dengan berjuang, lama-lama menjadi kebiasaan. Tidak ada bedanya dengan pencuri yang membiasakan dengan mencuri, dan tidak merasa takut lagi memasuki penjara itu karena memang sudah dipikirnya terlebih dahulu (HAMKA, 2015: 80).

2) Adab

Menurut (Al-Jurjani, 1988: 15), adab merupakan pengetahuan yang dapat menjauhkan seseorang yang beradab dari kesalahan-kesalahan.Terkait dengan adab, Syekh Muhammad An-Naquib Al-Atas mengatakan bahwa adab adalah ilmu tentang tujuan mencari pengetahuan. Sedangkan tujuan mencari pengetahuan dalam Islam ialah menanamkan kebaikan dalam diri manusia sebagai manusia dan pribadi (Al-Atas, 1987: 54). HAMKA membagi adab kepada tiga bagian, pertama adab kepada Allah swt, kedua adab kepada Nabi saw, dan ketiga adab kepada sesama.

1) Adab Kepada Allah swt

Menurut (HAMKA, 2015: 127), perasaan sopan santun dan adab kepada Allah swt yang timbul dari hati sanubari manusia, hati yang penuh dengan ketakwaan. Rasa takut dan cemas, rasa harap dan cinta, itu merupakan tanda-tanda iman yang sempurna. Itulah sebabnya di dalam ayat dan Hadis yang suci selalu dinyatakan bahwa, percuma amalan yang tumbuh seperti rukuk, sujud, berdiri dan duduk jika tidak disertai dengan keimanan dan ketakwaan denag sebenar-benarnya.

2) Adab Kepada Nabi saw

Semua manusia memiliki akal budi mesti merasa berhutang budi kepada Rasulullah saw, sebagaimana kepada ibu bapaknya, kepada gurunya, bahkan lebih dari itu. Tetapi bagaimana cara menghormati Nabi? Bukankah umat terdahulu banyak yang tersesat karena tidak tahu bagaimana cara menghormati Nabi dan Rasul-Nya, sehingga orang Nasrani mengatakan bahwa Nabi Isa adalah putera Allah swt, mereka anggap Isa Tuhan karena dapat menyembuhkan orang yang sakit, dapat menyembuhkan mata orang yang 
buta, dan lain sebagainya. Oleh karena itu, umat Islam diberi tuntunan oleh Allah swt, bagaimana cara menghormati Nabi saw (HAMKA, 2015: 124).

3) Adab Kepada Manusia

Selaku manusia tidak terlepas dari interaksi dan pergaulan terhadap lingkungannya, dalam kesopanan pergaulan harus menjaga perkataan dan perbuatan yang dapat menyakiti hati seseorang, itulah pentingnya adab dan kesopanan. Orang Barat menyebutnya etiket, misalnya menurut adat asli Indonesia. Merundukkan kepala jika lewat di depan orang tua, berbeda dengan di Eropa, apabila bertemu dengan seorang teman mengangkat topi memberi hormat, sedangkan pada bangsa Cina, mengangkat topi dilakukan ketika ia hendak pergi (HAMKA, 2015: 126). Jangan menaikkan jari kiri ketika berbicara, jangan menaikkan lutut ketika duduk didekat orang tua. Hendaklah berdiri seketika ada orang tua masuk dan berdiri pula sambil menghantarkannya keluar ketika orang tua itu akan pergi. Jangan meletakkan kopiyah diatas lutut, apabila pergi bertamu jangan memandang kesana kemari, dan perempuan tidak boleh tertawa dengan nada yang tinggi (HAMKA, 2015: 96).

4) Pembahasan

Secara umum, penelitian ini bertujuan untuk mengetahui pendidikan akhlak menurut HAMKA. Sebagaimana yang kita ketahui bahwa pendidikan saat ini mengalami dekadensi moral serta hilangnya nilai-nilai sosial yang banyak ditandai dengan adanya pergaulan bebas, minuman keras, tawuran antar pelajar, narkoba, dan masih banyak lagi yang lainnya. Hal ini adalah sebagian dari perilaku menyimpang remaja, pemuda, serta masyarakat. Apabila melihat kenyataan yang ada dalam kehidupan saat ini, banyak kasus yang menunjukkan bahwa akhlak bangsa Indonesia ini telah menurun.

Berangkat dari permasalahan diatas maka, sudah saatnya sistem pendidikan di Indonesia harus dibenahi tanpa meninggalkan jati diri bangsa Indonesia. Akhlak merupakan sesuatu yang penting bagi kehidupan. Akhlak merupakan aset seseorang untuk berinteraksi dengan sesamanya, akhlak juga mengatur hubungan manusia dengan segala yang ada dalam kehidupan di dunia ini, akhlak juga mengatur hubungan manusia dengan sang penciptanya.

Oleh karena itu, sebagai upaya penyusun untuk mengatasi masalah yang ada saat ini khususnya dalam dunia pendidikan akhlak, penyusun meneliti landasan pendidikan akhlak menurut HAMKA. Sebagaimana yang kita ketahui bahwa HAMKA adalah seorang tokoh pendidikan di Indonesia yang ikut meramaikan dinamika pendidikan Islam Itu sendiri. Meski berlatarbelakang pendidikan tradisional, namun tidak membuat pemikirannya tradisonal pula.

Menurut HAMKA akhlak adalah suatu persediaan yang ada, terhujam dan raasikh di dalam batin. Dialah yang menimbulkan perangai sehingga tidak perlu untuk berfikir kembali. Apabila persediaan itu tidak dapat menimbulkan perangai yang mulia (mulia menurut syara'), perangai yang terpuji, itulah yang 
dinamakan dengan akhlak yang baik. Namun, apabila yang berkembang ialah akhlak tercela menurut akal dan syara' maka otomatis dinamakan akhlak yang buruk. Dikatakan bahwa akhlak adalah perangai yang terhujam dalam batin, karena ada juga bersedia orang yang menafkahkan hartanya dengan ringan saja, tetapi tidak bersumber dari akhlak yang terhujam, semata-mata ada maksud dan tujuan didalamnya (HAMKA, 2017: 05-06). Akhlak yang mulia tidak akan timbul kaluar tidak dari sifat keutamaan. Keutamaan bisa dicapai dari perjuangan. Berebut-rebutan kedudukan, diantara akal dan nafsu. Awalnya di tempuh dengan berjuang untung akan mukjur menanglah akal. Setelah itu diajar, dibiasakan, sehingga menjadi perangai yang tetap. Pendidikan akhlak dapat diartikan dengan usaha sungguh-sungguh untuk mengubah akhlak buruk menjadi akhlak yang baik.

Dapat dipahami bahwa Pendidikan akhlak menurut HAMKA adalah suatu perangai dalam bathin yang dapat berubah sehingg apabila timbul berdasarkan akal dan agama maka, akan muncul perangai yang baik dan sebaliknya apabila timbul tidak berdasarkan agama maka, akan muncul perangai yang buruk atau sering disebut dengan akhlak tercela.

Dengan Pendidikan akhlak yang baik, seseorang akan menyongsong masa depan yang cerah, baik itu di dunia maupun di akhirat kelak. Kebutuhan terhadap Pendidikan akhlak sangatlah urgen karena pengaruh akhlak yang baik akan berdampak pada individu tersebut. Sebaliknya, akhlak buruk dari mengabaikan Pendidikan akhlak akan menimpa individu tersebut. Oleh sebab itu, sejak masa pertumbuhan anak atau peserta didik Pendidikan akhlak wajib mendapatkan perhatian yang serius dari setiap orang tua maupun pendidik (guru).

Sebagian besar, manusia yang menyimpang akhlaknya, tidak lain karena Pendidikan yang salah pada masa kecilnya. Menurut (Al-Jauziyah, 1391: 240), akhlak yang buruk ini akan menjadi sifat dan kepribadian yang tetap bagi seorang individu. Sehingga apabila seseorang berusaha keras untuk menghindarinya niscaya ia akan jatuh kembali kepada akhlak yang buruk tersebut. Oleh sebab itu, engkau dapati manusia menyimpang akhlaknya dan hal itu tidak lain dikarenakan Pendidikan saat ia tumbuh dan berkembang.

Meskipun tidak mustahil, tetapi sangatlah sulit untuk merubah akhlak buruk ke dalam akhlak yang baik, dan menghindari akhlak yang buruk harus dibiasakan sejak masih kecil. Demikian pula anak yang masih kecil harus dijauhkan dari majelis-majelis hiburan yang mengandung kesia-siaan, mendengarkan hal-hal yang kotor, dan kata-kata yang buruk. Karena jika katakata tersebut tersangkut pada pendengarannya maka, akan sulit bagi anak untuk meninggalkannya ketika ia sudah beranjak dewasa, dan akan sulit bagi orang tua atau pendidik untuk menghindarkan anak atau peserta didik dari kebiasaan-kebiasaan buruk yang pernah ia dengar atau lakukan sejak masih kecil. 
Sumber Pendidikan akhlak menurut HAMKA adalah Al-Qur'an Assunah, tauhid dan akal. HAMKA melihat untuk pembentukan akhlak yang baik dan mulia, harus memerlukan pemahaman dan pengalaman yang sangat mendalam terhadap Al-Qur'an dan Assunah. Keduanya merupakan pegangan hidup seorang yang beriman, sementara itu dengan bertauhid menyebabkan manusia terpandang harga diri dan bersedia mati untuk memperjuangkannya. HAMKA menyatakan bahwa pandangan hidup seorang muslim adalah tauhid, sehingga semua aktifitas hidup berdasarkan kepadanya, termasuk didalamnya akhlak. Kemudian HAMKA juga menempatkan akal pada posisi yang penting dalam diri manusia, dengan akal manusia dapat membedakan mana yang baik dan mana yang buruk, dan sebagai pembeda dengan makhluk yang lainnya sekaligus akal mempunyai kecerdasan yang menjadi nilai dan pertimbangan manusia dalam menjalani kehidupannya.

Keutamaan akhlak yang HAMKA bagi menjadi empat bagian diantaranya hikmah, syajaah, iffah, dan adalaah (bersikap adil). Hikmah yang Allah swt berikan kepada setiap hambanya agar manusia bisa lebih bijaksana dalam melakukan segala hal, karena hikmah lebih luas daripada ilmu. Syajaah yang berati berani atau gagah. Tetapi bukan berani dalam menentang siapa saja tanpa memperdulikan apakah dia berpihak kepada yang benar atau yang salah, dan bukan pula memperturutkan hawa nafsunya. Tetapi berani yang didasarkan pada kebenaran dan dilakukan dengan penuh pertimbangan. Keberanian tidaklah ditentukan oleh kekuatan fisik, tetapi ditentukan oleh kekuatan hati dan kebersihan jiwa. Banyak orang yang fisik dan jiwanya kuat, tetapi mempunyai hati yang lemah, pengecut. Sebaliknya betapa banyak yang mempunyai fisik lemah tetapi mempunyai hati siaga, hati yang seperti itu berani menghadapi setiap permasalahan. Kemampuan pengendalian diri di waktu marah, sekalipun dia mampu melampiaskannya, itulah contoh keberanian yang lahir dari hati yang kuat dan jiwa yang bersih. Iffah yang berarti menahan diri dari segala perbuatan yang tercela. Iffah adalah akhlak yang mulia, perbuatan yang baik, apabila seseorang selalu menghiasi dirinya dengan iffah maka Allah swt akan mencintainya dan akan dicintai oleh semua manusia. Dengan demikian, nilai seseorang tidak ditentukan dengan kekayaan dan jabatan, dan tidak pula ditentukan oleh bentuk rupanya, tetapi ditentukan oleh kehormatan dirinya. Terakhir adalaah (bersikap adil) pada hakikatnya pada hakikatnya adalah memperlakukan orang lain sesuai haknya atas kewajibannya yang telah dilakukan. Dan yang menjadi hak setiap orang adalah diakui dan diakui sesuai dengan harkat dan martabatnya, sama derajatnya, yang sama hak dan kewajibannya, tanpa membeda-bedakan suku, keturunan, agama, dan golongan. Keadilan ,merupakan suatu bentuk kondisi kebenaran ideal secara moral akan sesuatu hal, baik itu menyangkut benda ataupun orang. Keadilan mempunyai tingkat kepentingan yang sangat besar. Kebanyakan orang percaya jika ketidakadilan harus segera di lawan dan di 
hukum, serta banyak gerakan sosial politis yang ada di seluruh dunia memperjuangkan keadilan.

Dalam masalah menanamkan akhlak sering kali seseorang terdapat jarak antara pengetahuannya dengan perilaku mereka dalam kehidupan sehari-hari. Seseorang mengetahui tentang kebaikan tetapi belum tentu bias menjalankannya sendiri. Seseorang mengetahui bahwa berbohong, korupsi, khianat, dan sebagainya adalah perbuatan tercela, tetapi pada kenyataannya tidak semua orang yang mengetahuinya mampu meninggalkannya. Itu sebabnya problem Pendidikan akhlak adalah mendapatkan guru atau tauladan yang dapat di contoh. Problem terbesar tentang Pendidikan akhlak adalah orang yang mendidik harus terlebih dahulu menjalankannya. Dalam metode menanamkan akhlak HAMKA mengistilahkan dengan keutamaan dan adab kesopanan. Kesopanan tersebut termasuk kesopanan terhadap Allah swt, Rasulullah saw, dan kepada manusia.

\section{Kesimpulan}

Berdasarkan penelitian yang telah dilakukan tersebut di atas maka dapat diperoleh kesimpulan sebagai berikut: Landasan Pendidikan akhlak menurut HAMKA adalah suatu perangai dalam bathin yang dapat berubah sehingga apabila timbul berdasarkan akal dan agama maka akan muncul perangai yang baik dan sebaliknya apabila timbul tidak berdasarkan akal dan agama maka akan muncul perangai yang buruk atau sering disebut dengan akhlak tercela. Sumber pendidikan menurut HAMKA diantaranya: Al-Qur'an, Assunnah, Tauhid, dan akal. Keutamaan akhlak menurut HAMKA yaitu hikmah, syaja'aah, iffah, dan adalaah. Metode menanamkan akhlak kepada manusia menurut HAMKA diantaranya: keutamaan dan adab.

\section{DAFTAR PUSTAKA}

Al-Hamdani, M. D. (2018). Pendidikan Bernuansa Islam (1st ed.). Media Cetak Publisher.

Al-Jauziyah, M. bin A. B. A. az-Z. (1391). Tuhfatul Maudud bi Ahkam al-Maulud. Maktabah Dar al-Bayan.

Darojah, S. (2016). Metode Penanaman Akhlak dalam Pembentukan Perilaku Siswa MTs N Ngawen Gunungkidul. 1(2), 233-244.

Hamim, N. (2009). Manusia dan Pendidikan Elaborasi Pemikiran HAMKA. Qisthons.

HAMKA. (2015a). Dari Hati ke Hati (R. Anwar (ed.); 01 ed.). Gema Insani.

HAMKA. (2015b). Falsafah Hidup (M. I. Sanosa (ed.)). Republika Penerbit. HAMKA. (2015c). Tafsir Al-Azhar (01 ed.). Gema Insani Press.

HAMKA. (2017). Akhlakul Karimah (M. Hasan (ed.); 01 ed.). Gema Insani. 
HAMKA. (2018a). Lembaga Budi (M. I. Santosa (ed.); 03 ed.). PT Pustaka Abdi Bangsa.

Mohammad, H. (2006). Tokoh-Tokoh Islam yang Berpengaruh Pada Abad 20 (01 ed.). Gema Insani Press.

Muflihaini. (2017). Implementasi Pendidikan Akhlak dalam Membentuk Kepribadian Muslim Siswa di Madrasah Aliyah pp. Hidayatullah Tanjung Morawa.

Mustopa, M. (2014). Akhlak Mulia dalam Pandangan Masyarakat. Nadwa, 8(2), 261. https://doi.org/10.21580/nw.2014.8.2.581

Nata, A. (2010). Akhlak Tasawuf. Raja Grafindo Persada.

Nata, A. (2014). Akhlak Tasawuf dan Karakter Mulia. Raja Grafindo Persada.

Nizar, S. (2008). Memperbincangkan Dinamika Intelektual dan Pemikiran HAMKA Tentang Pendidikan Islam (01 ed.). Kencana.

Nur, R. (2016). Revolusi Akhlak (Pendidikan Karakter) (1st ed.). Tsamrt Printing.

Nurhidayat. (2017). Konsep Pendidikan Akhlak Bagi Peserta Didik Menurut Pemikiran Prof. Dr. HAMKA. 1-14.

Suprayogo, I., \& Tobroni. (2001). Metodologi Penelitian Sosial Agama. Remaja Rosda Karya.

Tafsir, A. (2016). Ilmu Pendidikan Islami (E. Kuswandi (ed.); 4th ed.). PT. Remaja Rosda Karya.

Zuriah, N. (2011). Pendidikan Moral dan Budi Pekerti dalam Perspektif Perubahan. Bumi Aksara. 